\title{
SANITATION ENVIRONMENTAL DETERMINANTS WITH EVENTS OF DIARRHEA IN CHILDREN IN RESIDENTIAL SOLID WORK AREA HEALTH PUBLIC HEALTH CENTER RUMBAI PEKANBARU CITY
}

\author{
Zulmeliza Rasyid, Rezki Meliyanti, Nurvi Susanti, Yessi Harnani
}

\author{
Program Studi Ilmu Kesehatan Masyarakat \\ STIKes Hang Tuah Pekanbaru \\ e-mail: zulmeliza.rasyid@gmail.com
}

\begin{abstract}
Diarrhea is a condition where a person defecating with soft or liquid consistency (three times or more) in one day. Pekanbaru City Health Department data obtained by the number of diarrhea cases in Puskesmas Rumbai handled in 2013 totaled 670 cases (28\%), the year 2014 amounted to 827 cases (35\%). The purpose of this study is Knowledgeable picture and determinants of environmental sanitation with the incidence of diarrhea in infants in the densely populated area Puskesmas Rumbai Pekanbaru

This type of research is an analytic-quantitative with cross sectional design. The sample amounted to 102 infants. Methods of data collection is done by interviews and data collection tools were questionnaires. Quota sampling using sampling techniques. Computerized data processing. The data analysis univariate and bivariate with chi-square test.

The results were obtained landfills value of $p=0.001$ and $O R=3.13$, waste water management, with $p=$ 0.004 and $O R=3.60$, type of latrine with a value of $p=0.002$ and $O R=5.60$, the distance means clean water cesspools with $p=0.001$ and $O R=10.29$. So we can conclude all the variables associated with the incidence of diarrhea in the densely populated area Puskesmas Rumbai Pekanbaru

It is expected that the health center Rumbai Pekanbaru doing outreach to the community about the importance of environmental sanitation hygiene so that children are not susceptible to diarrheal diseases.
\end{abstract}

Key words: Environmental Sanitation, diarrhea, Toddler, Residential Solid

\section{PENDAHULUAN}

Diare adalah salah satu kondisi dimana seseorang buang air besar dengan konsistensi lembek atau cair, bahkan dapat berupa air saja dan frekuensinya lebih sering (biasanya tiga kali atau lebih) dalam satu hari. Diare akut sering disertai dengan tanda dan gejala klinis lainnya seperti muntah, demam, dehidrasi dan gangguan elektrolit. Keadaan ini merupakan gejala infeksi yang disebabkan oleh bakteri, virus dan parasit perut. Diare salah satu penyakit menular yang menyebabkan kematian balita. Walaupun beberapa tahun terakhir ini sejumlah penyakit menular tertentu sudah dapat diatasi, tetapi sampai saat ini penyakit diare masih menjadi masalah kesehatan dunia (Irianto, 2014).

Di dunia, diare membunuh 2 juta balita setiap tahun. Satu dari lima orang menderita diare setiap tahunnya, dan satu dari enam orang pasien yang berobat ke praktek umum menderita diare. Tingginya kejadian diare oleh karena foodborne infections dan water born infections yang disebabkan bakteri salmonella spp, Campylobacteri jejuni, Stafhilococcus aureus, Bacillus cereus, Clostridium perfringrns dan Enterohemorrhagic Escherichia coli (EHEC) (Depkes, 2010).

Di negara berkembang diare menyebabkan kematian, sekitar 3 juta penduduk setiap tahun. Di Afrika balita terserang infeksi diare 7 kali setiap tahunnya dibandingkan di negara berkembang lainnya mengalami serangan diare 3 kali setiap tahun. Kematian balita dinegara berkembang diperkirakan meningkat dari 2,9 juta kematian pada tahun 2004 menjadi 4,5 juta kematian pada tahun 2011 (Depkes, 2010).

Di Indonesia diare menduduki rangking keenam dengan angka kejadian sekitar 6 juta bayi yang mati pertahunnya. Angka kematian akibat diare di Indonesia pada tahun 2007, sebanyak 72 dari 4.032 penderita diare, tahun 2008 sebanyak 239 dari 8.133 penderita, tahun 2009 sebanyak 100 dari 5.756 penderita, dan tahun 2010 sebanyak 73 dari 4.204 penderita, data terakhir tahun 2011 sebanyak 12 dari 3.003 penderita diare. Angka kejadian diare masih tergolong tinggi, di Indonesia, selain itu juga 
bisa menyebabkan kematian (Kemenkes RI, 2011).

Di Provinsi Riau cakupan penemuan dan penanganan diare pada balita di Provinsi Riau tahun 2012 sebesar 20,6\%, lebih rendah dibanding tahun 2011 (58,8\%). Pada tingkat kabupaten/kota, diketahui bahwa cakupan penemuan dan penanganan diare tertinggi adalah Kota Dumai $(31,2 \%)$ dan terendah adalah Kota Pekanbaru (9,8\%). Sedangkan jumlah penderita diare pada balita di Provinsi Riau yang ditangani pada tahun 2011 yaitu berjumlah 113,426 kasus. Dan penderita diare pada balita mengalami peningkatan pada tahun 2012 yaitu sebanyak 262.202 kasus (Dinkes Riau, 2012).

Adapun Prevalensi diare klinis adalah 9,0\% (rentang 4,2\% - 18,9\%), tertinggi di Provinsi Nanggroe Aceh Darussalam (NAD) (18,9\%) dan terendah di DI Yogyakarta $(4,2 \%)$. Beberapa provinsi mempunyai prevalensi diare klinis $>9 \%$ (NAD, Sumatera Barat, Riau, Jawa Barat, Jawa Tengah, Banten, Nusa Tenggara Barat, Nusa Tengara Timur, Kalimantan Selatan, Sulawesi Tengah, Sulawesi Tenggara, Gorontalo, Papua Barat dan Papua). Bila dilihat per kelompok umur diare tersebar di semua kelompok umur dengan prevalensi tertinggi terdeteksi pada balita (1-4 tahun) yaitu $16,7 \%$. Sedangkan menurut jenis kelamin prevalensi laki-laki dan perempuan hampir sama, yaitu $8,9 \%$ pada laki-laki dan $9,1 \%$ pada perempuan (Kemenkes RI, 2011).

Penyebab balita mudah terserang penyakit diare adalah perilaku hidup masyarakat yang kurang baik dan keadaan lingkungan yang buruk. Diare dapat berakibat fatal apabila tidak ditangani secara serius karena tubuh balita sebagian besar terdiri dari air, sehingga bila terjadi diare sangat mudah terkena dehidasi (Depkes, 2010).

Faktor risiko yang meningkatkan kejadian diare pada balita yaitu faktor sanitasi lingkungan (pembuangan sampah, pengelolaan air limbah, sumber air minum, jenis jamban dan kebersihan jamban) (Bintoro, 2010). Faktor perilaku (pemberian ASI eksklusif, kebiasaan mencuci tangan dan pemberian imunisasi) (Amaliah, 2009).

Data yang diperoleh dari Dinas Kesehatan Kota Pekanbaru, di Wilayah Kerja Puskesmas Rumbai, jumlah kasus diare yang ditangani pada tahun 2013 yaitu berjumlah 670 kasus diare dan proporsi kasus diare pada balita yaitu 28\%. Sedangkan pada tahun 2014 yaitu berjumlah 827 kasus diare, dimana proporsi kasus diare pada balita yaitu sebesar 35\% (Dinkes Kota Pekanbaru, 2014).

Berdasarkan survei awal dan observasi yang dilakukan di Perumahan padat penduduk wilayah kerja Puskesmas Rumbai Kota Pekanbaru, diperoleh data bahwa dari 10 rumah diketahui bahwa terdapat 7 rumah $(70 \%)$ yang sanitasi lingkungannya tercemar. Hasil observasi diketahui bahwa tempat pembuangan sampah tidak ada di masing-masing rumah dan tidak dikelola dengan baik, penampungan air limbah tidak tertutup sehingga menimbulkan bau, dan jarak sarana air bersih dengan septik tank $<10$ meter.Berdasarkan latar belakang diatas maka peneliti tertarik untuk meneliti tentang "Hubungan Sanitasi Lingkungan Dengan Kejadian Diare Pada Balita Di Perumahan Padat Penduduk Wilayah Kerja Puskesmas Rumbai Kota Pekanbaru Tahun 2016 ".Tujuan penelitian ini adalah diketahuinya gambaran determinan sanitasi lingkungan dengan kejadian diare pada balita di perumahan padat penduduk wilayah kerja Puskesmas Rumbai Kota Pekanbaru Tahun 2016.

\section{METODOLOGI PENELITIAN}

Jenis penelitian ini adalah bersifat analitik kuantitatif observational dengan desain cross sectional. Sampel dalam penelitian berjumlah 102 balita. Metode pengumpulan data dilakukan dengan wawancara dan observasi. Alat pengumpulan data yang digunakan adalah kuesioner. Pengambilan sampel dalam penelitian ini menggunakan tehnik Quota sampling. Pengolahan data dilakukan secara komputerisasi. Analisa data secara univariat dan bivariat dengan uji chi-square. 


\section{HASIL DAN PEMBAHASAN}

Hasil

Hubungan antara Pembuangan Sampah dengan Kejadian Diare Pada Balita

Tabel 1

Hubungan antara Pembuangan Sampah dengan Kejadian Diare Pada Balita di Perumahan Padat Penduduk Wilayah Kerja Puskesmas Rumbai Kota

Pekanbaru Tahun 2016

\begin{tabular}{|c|c|c|c|c|c|c|c|}
\hline \multirow[t]{3}{*}{ Pembuangan Sampah } & \multicolumn{5}{|c|}{ Kejadian Diare } & \multirow{3}{*}{ P Value } & \multirow{3}{*}{$\begin{array}{c}\text { POR } \\
(95 \% \mathrm{CI})\end{array}$} \\
\hline & \multicolumn{2}{|c|}{ Diare } & \multicolumn{2}{|c|}{ Tidak Diare } & \multirow{2}{*}{$\begin{array}{c}\text { Total } \\
\text { n (\%) }\end{array}$} & & \\
\hline & $\bar{n}$ & $\%$ & $\bar{n}$ & $\%$ & & & \\
\hline Memenuhi Syarat & 4 & 10,8 & 33 & 89,2 & $37(100)$ & & $(9,10-99,22)$ \\
\hline Jumlah & 55 & 53,9 & 47 & 46,1 & $102(100)$ & & \\
\hline
\end{tabular}

Berdasarkan tabel diatas diperoleh bahwa dari 65 responden yang tempat pembuangan sampah tidak memenuhi syarat, terdapat 51 orang $(78,5 \%)$ balitanya pernah mengalami kejadian diare. sedangkan dari 37 responden yang tempat pembuangan sampah memenuhi syarat terdapat 4 orang $(10,8 \%)$ balitanya pernah mengalami kejadian diare.

Hasil uji statistik diperoleh nilai $\mathrm{p}$ value $=0,001(<0,05)$, maka dapat disimpulkan ada hubungan yang signifikan antara pembuangan sampah dengan kejadian diare pada balita di perumahan padat penduduk wilayah kerja Puskesmas Rumbai Kota Pekanbaru Tahun 2016.

Juga diperoleh nilai POR (Prevalensi Odds Ratio) $=30,05$ (CI 95\%: 9,10-99,22), ini berarti bahwa tempat pembuangan sampah yang tidak memenuhi syarat, beresiko sebesar 30 kali menyebabkan kejadian diare pada balita dibandingkan dengan tempat pembuangan sampah yang memenuhi syarat.

\section{Hubungan antara Pengelolaan Air Limbah dengan Kejadian Diare Pada Balita}

Tabel 2

Hubungan antara Pengelolaan Air Limbah dengan Kejadian Diare Pada Balita di Perumahan Padat Penduduk Wilayah Kerja Puskesmas Rumbai

Kota Pekanbaru Tahun 2016

\begin{tabular}{|c|c|c|c|c|c|c|c|}
\hline \multirow[t]{3}{*}{ Pengelolaan Air Limbah } & \multicolumn{5}{|c|}{ Kejadian Diare } & \multirow{3}{*}{ P Value } & \multirow{3}{*}{$\begin{array}{c}\text { POR } \\
(95 \% \text { CI })\end{array}$} \\
\hline & \multicolumn{2}{|c|}{ Diare } & \multicolumn{2}{|c|}{ Tidak Diare } & \multirow{2}{*}{$\frac{\text { Total }}{\text { n (\%) }}$} & & \\
\hline & $\mathbf{n}$ & $\%$ & $\mathbf{n}$ & $\%$ & & & \\
\hline Tidak Memenuhi Syarat & 4 & 66,7 & 20 & 33,3 & $60(100)$ & 0,004 & $\begin{array}{c}3,60 \\
(1,57-8,24)\end{array}$ \\
\hline Memenuhi Syarat & 1 & 35,7 & 27 & 64,3 & $42(100)$ & & $(9,10-99,22)$ \\
\hline Jumlah & 5 & $\mathbf{5 3 , 9}$ & 47 & 46,1 & $102(100)$ & & \\
\hline
\end{tabular}

Berdasarkan tabel diatas diperoleh bahwa dari 60 responden yang pengelolaan air limbahnya tidak memenuhi syarat, terdapat 40 orang $(66,7 \%)$ balitanya pernah mengalami kejadian diare. Sedangkan dari 42 responden yang pengelolaan air limbahnya memenuhi syarat, terdapat 15 orang $(35,7 \%)$ balitanya pernah mengalami kejadian diare.

Hasil uji statistik diperoleh nilai $\mathrm{p}$ value $=0,004 \quad(<0,05)$, maka dapat disimpulkan bahwa, ada hubungan yang signifikan antara pengelolaan air limbah dengan kejadian diare pada balita di perumahan padat penduduk wilayah kerja Puskesmas Rumbai Kota Pekanbaru Tahun 2016.

Dari uji statistik tersebut juga diperoleh nilai POR (Prevalensi Odds Ratio) $=3,60$ (CI 95\%: 1,57-8,24), hal ini berarti bahwa pengelolaan air limbah yang tidak memenuhi syarat beresiko sebesar 3,60 kali menyebabkan kejadian diare pada balita dibandingkan dengan pengelolaan air limbah yang memenuhi syarat. 
Hubungan antara Jenis Jamban dengan Kejadian Diare Pada Balita

Tabel 3

Hubungan antara Jenis Jamban dengan Kejadian Diare Pada Balita di Perumahan Padat Penduduk Wilayah Kerja Puskesmas Rumbai Kota Pekanbaru Tahun 2016

\begin{tabular}{|c|c|c|c|c|c|c|c|}
\hline \multirow[t]{3}{*}{ Jenis Jamban } & \multicolumn{5}{|c|}{ Kejadian Diare } & \multirow{3}{*}{ P Value } & \multirow{3}{*}{$\begin{array}{c}\text { POR } \\
(95 \% \mathrm{CI})\end{array}$} \\
\hline & \multicolumn{2}{|c|}{ Diare } & \multicolumn{2}{|c|}{ Tidak Diare } & \multirow{2}{*}{$\begin{array}{l}\text { Total } \\
\text { n (\%) }\end{array}$} & & \\
\hline & $n$ & $\%$ & $\bar{n}$ & $\%$ & & & \\
\hline Tidak Memenuhi Syarat & 22 & 81,5 & 5 & 18,5 & $27(100)$ & 0,002 & 5,6 \\
\hline Memenuhi Syarat & 33 & 44 & 42 & 56 & $75(100)$ & & $\begin{array}{l}(1,91- \\
16,37)\end{array}$ \\
\hline Jumlah & 55 & 53,9 & 47 & 46,1 & $102(100)$ & & \\
\hline
\end{tabular}

Berdasarkan tabel diatas diperoleh bahwa dari 27 responden yang jenis jambannya tidak memenuhi syarat, terdapat 22 orang $(81,5 \%)$ balitanya pernah mengalami kejadian diare. sedangkan dari 75 responden yang jenis jambannya memenuhi syarat terdapat 33 orang (44\%) balitanya pernah mengalami kejadian diare.

Hasil uji statistik diperoleh nilai $p$ value $=0,002(<0,05)$, maka dapat disimpulkan bahwa, ada hubungan yang signifikan antara jenis jamban dengan kejadian diare pada balita di perumahan padat penduduk wilayah kerja Puskesmas Rumbai Kota Pekanbaru Tahun 2016.

Dari uji statistik tersebut juga diperoleh nilai POR (Prevalensi Odds Ratio) $=5,60(\mathrm{CI}$ 95\%: 1,91-16,37), hal ini berarti bahwa jenis jamban yang tidak memenuhi syarat beresiko sebesar 5,60 kali menyebabkan kejadian diare pada balita dibandingkan dengan jenis jamban yang memenuhi syarat.

Hubungan antara Jarak Sarana air Bersih dengan Septik Tank dengan Kejadian Diare Pada Balita

Tabel 4

Hubungan antara Jarak Sarana air Bersih dengan Septik Tank dengan Kejadian Diare Pada Balita di Perumahan Padat Penduduk Wilayah Kerja Puskesmas Rumbai Kota Pekanbaru Tahun 2016

\begin{tabular}{|c|c|c|c|c|c|c|c|}
\hline \multirow{3}{*}{$\begin{array}{c}\text { Jarak Sarana Air Bersih } \\
\text { dengan Septik Tank }\end{array}$} & \multicolumn{5}{|c|}{ Kejadian Diare } & \multirow{3}{*}{$\begin{array}{c}\mathbf{P} \\
\text { Value }\end{array}$} & \multirow{3}{*}{$\begin{array}{c}\text { POR } \\
(95 \% \mathrm{CI})\end{array}$} \\
\hline & \multicolumn{2}{|c|}{ Diare } & \multicolumn{2}{|c|}{$\begin{array}{l}\text { Tidak } \\
\text { Diare }\end{array}$} & \multirow{2}{*}{$\frac{\text { Total }}{\text { N (\%) }}$} & & \\
\hline & $\mathbf{N}$ & $\%$ & $\mathbf{N}$ & $\%$ & & & \\
\hline Tidak Memenuhi Syarat & 51 & 66,2 & 26 & 33,8 & $77(100)$ & \multirow{3}{*}{0,001} & \multirow{3}{*}{$\begin{array}{c}10,29 \\
(3,2-33,14)\end{array}$} \\
\hline Memenuhi Syarat & 4 & 16 & 21 & 84 & $25(100)$ & & \\
\hline Jumlah & 55 & 53,9 & 47 & 46,1 & $102(100)$ & & \\
\hline
\end{tabular}

Berdasarkan tabel diatas diperoleh bahwa dari 77 responden yang jarak sarana air bersih dengan septik tank tidak memenuhi syarat, terdapat 51 orang $(66,2 \%)$ balitanya pernah mengalami diare. sedangkan dari 25 responden yang jarak sarana air bersih dengan septik tank memenuhi syarat, terdapat 4 orang (16\%) balitanya pernah mengalami diare.

Hasil uji statistik diperoleh nilai $\mathrm{p}$ value $=0,001 \quad(<0,05)$, maka dapat disimpulkan bahwa, ada hubungan yang signifikan antara jarak sarana air bersih dengan septik tank dengan kejadian diare pada balita di perumahan padat penduduk wilayah kerja Puskesmas Rumbai Kota Pekanbaru Tahun 2016.

Dari uji statistik tersebut juga diperoleh nilai POR (Prevalensi Odds Ratio) $=10,29$ (CI 95\%: 3,2-33,14), hal ini berarti bahwa jarak sarana air bersih dengan septik tank yang tidak memenuhi syarat beresiko sebesar 10,29 kali 
menyebabkan kejadian diare pada balita dibandingkan dengan jarak sarana air bersih dengan septik tank yang memenuhi syarat.

\section{Pembahasan}

\section{Hubungan antara pembuangan sampah dengan kejadian diare pada balita}

Berdasarkan hasil penelitian diatas didapatkan hasil penelitian $\mathrm{p}$ value $=0,001$. Hal ini menunjukkan adanya hubungan yang bermakna antara tempat pembuangan sampah dengan kejadian diare pada balita di perumahan padat penduduk wilayah kerja Puskesmas Rumbai Kota Pekanbaru Tahun 2016. Sedangkan dari uji statistik tersebut juga menunjukkan bahwa, tempat pembuangan sampah yang tidak memenuhi syarat beresiko sebesar 30 kali menyebabkan kejadian diare pada balita dibandingkan dengan tempat pembuangan sampah yang memenuhi syarat.

Tempat pembuangan sampah yaitu ruang yang dipakai untuk menaruh, menyimpan dan mengumpulkan sampah. Adanya tempat pembuangan sampah menghindari kebiasaan membuang sampah sembarangan yang dapat mengganggu keindahan dan kesehatan lingkungan serta etika sosial (Umiati, 2010).

Hasil penelitian sesuai dengan hasil penelitian yang dilakukan Bintoro (2010), yaitu ada hubungan antara pembuangan sampah dengan kejadian diare pada balita di kecamatan Jatipuro Kabupaten Karanganyar dengan nilai $p$ value $=0,005$

Menurut asumsi peneliti, masyarakat yang memiliki tempat pembuangan sampah yang tidak memenuhi syarat di rumah, akan membuang sampah sembarangan sehingga mengakibatkan sampah menumpuk, dan menimbulkan bau yang tidak sedap serta pemandangan yang buruk karena sampah akan bertebaran dimana-mana. Sampah yang menumpuk tersebut tentunya akan banyak mengganggu masyarakat, disamping menimbulkan bau yang tak sedap, sampah inipun dapat menimbulkan penyakit. Di perumahan padat penduduk wilayah kerja Puskesmas Rumbai Kota Pekanbaru, kondisi lingkungan di sekitar perumahan sangat padat dan sampah berserakan di lingkungan sekitar. Masyarakat banyak yang tidak punya tempat pembuangan sampah sehingga sampah yang berserakan banyak dihinggapi vektor dan menyebabkan tempat bersarangnya vektor seperti lalat, lalat dapat hinggap di makanan yang tidak tertutup sehingga penularan dari lalat dapat menyebabkan penyakit diare pada balita

\section{Hubungan antara pengelolaan air limbah dengan kejadian diare pada balita}

Berdasarkan hasil penelitian diatas didapatkan hasil $p$ value $=0,004$. Hal ini menunjukkan adanya hubungan yang signifikan antara pengelolaan air limbah dengan kejadian diare pada balita di perumahan padat penduduk wilayah kerja Puskesmas Rumbai Kota Pekanbaru Tahun 2016. Sedangkan dari uji statistik tersebut juga menunjukkan bahwa, pengelolaan air limbah yang tidak memenuhi syarat beresiko sebesar 3,60 kali menyebabkan kejadian diare pada balita dibandingkan dengan pengelolaan air limbah yang memenuhi syarat.

Pengelolaan air limbah merupakan proses penghilangan kontaminan dari air limbah. Tujuan dari pengelolaan limbah adalah mencegah pencemaran lingkungan, dan tidak menimbulkan kerugian atau masalah kepada masyarakat. Dengan pengelolaan limbah yang baik maka lingkungan tidak akan tercemar dan lingkungan menjadi sehat (Maritza, 2012).

Hasil penelitian ini sejalan dengan penelitian yang dilakukan oleh Bintoro (2010), yaitu ada hubungan antara pengelolaan air limbah dengan kejadian diare pada balita di kecamatan Jatipuro Kabupaten Karanganyar dengan nilai $\mathrm{p}$ value $=0,026$

Menurut asumsi peneliti, pengelolaan air limbah yang tidak memenuhi syarat di lingkungan sekitar rumah seperti pembuangan air limbah tidak lancar, saluran air limbah terbuka, penampungan air limbah terbuka dan di sekitar penampungan air limbah terdapat lalat akan mencemari sumber air minum, mencemari permukaan tanah dan menjadi tempat berkembangbiaknya bibit penyakit dan vektor. Air limbah yang tergenang disekitar lingkungan perumahan membuat lalat banyak hinggap di 
halaman sekitar perumahan sehingga menimbulkan gangguan kesehatan dan menjadi sumber penyebaran penyakit diare pada balita.

\section{Hubungan antara jenis jamban dengan kejadian diare pada balita}

Berdasarkan hasil penelitian diatas didapat hasil penelitian $p$ value $=0,002$. Hal ini menunjukkan ada hubungan yang signifikan antara jenis jamban dengan kejadian diare pada balita di perumahan padat penduduk wilayah kerja Puskesmas Rumbai Kota Pekanbaru Tahun 2016. Sedangkan dari uji statistik tersebut juga menunjukkan bahwa, jenis jamban yang tidak memenuhi syarat beresiko sebesar 5,60 kali menyebabkan kejadian diare pada balita dibandingkan dengan jenis jamban yang memenuhi syarat.

Jamban adalah suatu bangunan yang digunakan untuk membuang dan mengumpulkan kotoran manusia dalam suatu tempat tertentu, sehingga kotoran tersebut dalam suatu tempat tertentu tidak menjadi penyebab penyakit dan mengotori lingkungan pemukiman. Jenis jamban tidak sehat yang dapat menyebabkan penyakit diare pada balita yaitu jenis jamban tanpa tangki septik atau jamban cemplung dan rumah yang tidak memiliki jamban sehingga bila buang air besar mereka pergi ke sungai. Jenis tempat pembuangan tinja yang tidak memenuhi syarat kesehatan, akan berdampak pada banyaknya lalat. Tinja yang dibuang di tempat terbuka dapat digunakan oleh lalat untuk bertelur dan berkembang biak. Lalat berperan dalam penularan penyakit melalui tinja (faecal borne disease) (Hardi, 2012).

Hasil penelitian ini sejalan dengan penelitian yang dilakukan oleh Bintoro (2010), yaitu ada hubungan antara jenis jamban dengan kejadian diare pada balita di kecamatan Jatipuro Kabupaten Karanganyar dengan nilai $\mathrm{p}$ value $=0,029$ dan $\mathrm{OR}=2,42$.

Menurut asumsi peneliti jenis jamban merupakan bagian dari usaha sanitasi yang cukup penting peranannya. Masyarakat yang membuang tinja sembarangan, dapat mencemari tanah dan air tanah yang akhirnya akan mempengaruhi kesehatan manusia. Tinja juga dapat merupakan sumber penularan penyakit, terutama penyakit saluran pencernaan, salah satunya penyakit diare. Masyarakat harus tahu dan mengerti arti pentingnya mempunyai jamban sendiri di rumah yaitu jamban leher angsa, serta adanya kesadaran masyarakat untuk menerapkan pola hidup sehat dengan tidak Buang Air Besar sembarangan yang membuat lingkungan sekitar perumahan menjadi tercemar.

\section{Hubungan antara Jarak Sarana Air Bersih dengan Septik Tank dengan Kejadian Diare Pada Balita}

Berdasarkan hasil penelitian diatas didapatkan hasil penelitian $p$ value $=0,001$. Hal ini menunjukkan ada hubungan yang signifikan antara jarak sarana air bersih dengan septik tank dengan kejadian diare pada balita di perumahan padat penduduk wilayah kerja Puskesmas Rumbai Kota Pekanbaru Tahun 2016. Sedangkan dari uji statistik tersebut juga menunjukkan bahwa, jarak sarana air bersih dengan septik tank yang tidak memenuhi syarat beresiko sebesar 10,29 kali menyebabkan kejadian diare pada balita dibandingkan dengan jarak sarana air bersih dengan septik tank yang memenuhi syarat.

Jarak sarana air bersih dengan septik tank yaitu 10 meter, agar air tidak terkontaminasi dengan air tangki septic oleh bakteri patogen yang dapat mengganggu kesehatan. Jarak 10 meter antara sarana air bersih dan tangki septic bermula dari bakteri E-coli patogen (bersifat anaerob) yang biasanya mempunyai usia harapan hidup selama tiga hari. Sedangkan kecepatan aliran air dalam tanah berkisar 3 meter per hari (rata-rata kecepatan aliran air dalam tanah 3 meter/hari), sehingga jarak ideal antara tangki septik dengan sarana air bersih sejauh 3 meter per hari x 3 hari $=9$ meter dan ditambah satu meter sebagai jarak pengaman (Umiati, 2010).

Hasil penelitian ini sejalan dengan penelitian yang dilakukan oleh Candra (2013), yaitu ada hubungan antara sarana air bersih dengan kejadian diare pada balita di Desa 
Denbantas Kabupaten Tabanan Tahun 2013 yaitu dengan nilai $\mathrm{p}$ value $=0,000$.

Menurut asumsi peneliti, jarak sarana air bersih yang digunakan untuk keperluan seharihari seperti sumur, harus memenuhi syarat kesehatan sebagai air bagi rumah tangga, maka air harus dilindungi dari pencemaran. Masyarakat di perumahan harus membuat jarak sarana air bersih dengan septik tank yaitu 10 meter, agar air tidak terkontaminasi dengan air tangki septik. Sarana air bersih yang tercemar oleh bakteri (Escherichia coli) jika dikonsumsi oleh balita maka dapat menyebabkan kejadian diare pada balita. Di perumahan padat penduduk masih banyak yang jarak sarana ar bersih dengan septik tank $>10$ meter, karena kebanyakan dari masyarakat tidak membangun ulang lagi kondisi septik tank setelah mereka menempati perumahan tersebut.

\section{KESIMPULAN}

Kesimpulan dari penelitian ini adalah terdapat hubungan antara pembuangan sampah (p value $=0,001, \mathrm{POR}=30, \mathrm{CI} 95 \%: 9,10$ 99,22), pengelolaan air limbah ( $\mathrm{p}$ value $=0,004$, $\mathrm{POR}=3,60$, CI 95\%: 1,57-8,24), jenis jamban ( $\mathrm{p}$ value $=0,002, \mathrm{POR}=5,60$, CI 95\%: 1,91-16,37), jarak sarana air bersih dengan septik tank dengan kejadian diare ( $\mathrm{p}$ value $=0,001$, $\mathrm{POR}=10,29$, CI 95\%: 3,2-33,14) dengan kejadian diare wilayah kerja Puskesmas Rumbai Kota Pekanbaru Tahun 2016.

\section{DAFTAR PUSTAKA}

Amaliah, S. (2009). Hubungan Sanitasi Lingkungan dan Faktor Budaya dengan

Kejadian Diare Pada Anak Balita di Desa Toriyo Kecamatan Bendosari

Kabupaten Sukoharjo. Universitas

Muhammadiyah Semarang: Fakultas

Kedokteran.

Bintoro, B.R.T. (2010). Hubungan Antara Sanitasi Lingkungan dengan Kejadian Diare

Pada Balita di Kecamatan Jatipuro Kabupaten Karanganyar. Universitas Muhammadiyah Surakarta: Program Studi Kesehatan Masyarakat.
Candra, Y., M. Choirul Abdi., Anysiah Elly Yulianty. (2013). Hubungan Antara

Kejadian Sanitasi Sarana Air Bersih dengan Kejadian Diare Pada Balita di Desa Denbantas Tabanan Tahun 2013. Poltekes Denpasar.

Depkes. RI. (2011). Buku Saku Petugas Kesehatan Lintas Diare. Direktorat Jenderal

Pengendalian Penyakit dan Penyehatan Lingkungan.

(2010). Buku Pedoman Pengendalian Penyakit Diare, Jakarta: Ditjen PPM \& PL.

Dinkes Kota pekanbaru. (2014). Profil Kesehatan Kota Pekanbaru.

Dinkes Provinsi Riau. (2012). Profil Kesehatan Provinsi Riau.

Hardi, A. R., Masni., Rahma. (2012). FaktorFaktor yang Mempengaruhi Kejadian

Diare Pada Batita di Wilayah Kerja Puskesmas Baranglompo Kecamatan

Ujung Tanah Tahun 2012. Universitas Hasanudin Makasar: Fakultas Kesehatan Masyarakat.

Irianto, K. (2014). Epidemiologi Penyakit Menular dan Tidak Menular Panduan Klinis.

Bandung: Alfabeta.

KeMenKes, R.I. (2011). Panduan Sosialisasi Tatalaksana Diare Balita. Kementrian

Kesehatan Republik Indonesia. (2011). Buletin Jendela Data dan Informasi Kesehatan Situasi Diare di Indonesia. Kementrian Kesehatan Republik Indonesia.

Umiati. (2010). Hubungan Antara Sanitasi Lingkungan dengan Kejadian Diare Pada

Balita di Wilayah Kerja Puskesmas Nogosari Kabupaten Boyolali. Universitas

Muhammadiyah Surakarta: Program Studi Kesehatan Masyarakat. 